\title{
RESIDENTIAL OPPORTUNITIES AND EMANCIPATION STRATEGIES IN AN OWNER-OCCUPIED DOMINATED MARKET
}

\author{
Montserrat Pareja-Eastaway \\ Departament de Teoria Econòmica \\ Universitat de Barcelona
}

Remisión Artículo: 3-9-2007

Key words: Emancipation strategies, housing opportunities, tenure, housing career

\begin{abstract}
Different events in the life course of individuals are normally associated with specific residential choices. In particular, this applies to the process of household formation which, from the residential perspective, involves moving from the parental house to another dwelling. Emancipation evidences the preferences of young people for a new habitat and is usually conditioned by two sets of variables: on the one hand, labour conditions (i.e. a permanent job, the amount of salary, etc.) and, on the other, the residential opportunities offered by the current market circumstances. Certainly, a secure occupation in the labour market facilitates the affordability of rent or mortgage payments. Besides, the better the position is, the broader the range of housing opportunities. However, the housing market situation and, therefore, the existence or not of available/affordable residential opportunities for new households might influence delays or earlier moves in the process of emancipation.
\end{abstract}

This article will focus on the impact of a certain residential landscape dominated by owneroccupation and high rents and prices, the Spanish housing market, in the process of emancipation and residential decisions of young households. The hypothesis to be tested in this particular context refers to the effects of how scarce affordable residential opportunities have affected the process of young people emancipation. In particular, the recent growth of housing prices and rents together with the insufficient renting opportunities in the market will be analysed under the light of housing careers' literature: the residential choice of young people is therefore understood as a combination of housing preferences of population and constraints imposed by the market. Finally, given the current deceleration of the Spanish housing market (i.e. less construction and lower housing prices growth rate) and the changing macroeconomic landscape, especially the hardening of the financial conditions, some hints about those recently emancipated will be offered. 


\section{Emancipation and housing market; some introductory facts.}

Emancipation designates the move from the parental home to a chosen shelter. It is the beginning of the housing career of individuals. The decision is governed by well-known socioeconomic facts such as economic stability, and where housing certainly plays a definite role. Since access to housing along with access to work, health care, and education, is a central element of the operation of modern urban societies (Clark and Dieleman, 1996), guarantees for the emancipation process to happen in an adequate manner are needed. Nowadays and not by chance, adequate housing provision for young people features in many European policy agendas.

Many circumstances have favoured the extension of the period for a person to be considered as "young". An increase in the number of years addressed to acquire education; difficulties in finding a stable job and the modern societal trend of postponing compromise among young people have determined a considerable delay in the process of household formation. The evolution of the housing market together with the diminishing residential opportunities offered to new households has, unquestionably, accentuated this trend

Two issues must be considered when analysing emancipation: on the one hand, the average age of emancipation for young people. On the other, the rate of emancipation which corresponds to the relationship between those aged 18 to 35, who are already emancipated, and the total amount of people belonging to this range of age. This consideration becomes relevant because it might denote different trends, as it occurs in Spain, which might be explained by distinct facts.

During the past decades, the tendency for young people to leave the parental home at a later age has become evident not only in Southern countries but also in the rest of Europe. According to the Flash Eurobarometer -Youth Survey conducted in 2007, when asked why, a majority of young Europeans give economic reasons; "they can't afford to move out" (44\%), "there is not enough affordable housing available" $(28 \%)$ and "they want all the home comforts without the responsibilities" (16\%) were the three most main reasons selected. Taking into account that those countries with high levels of owner-occupied dwellings (Italy, Spain and Greece) are usually connected with late nest-leavers, it could be possible to argue that this unbalanced tenure situation might lead to a late start in the housing careers of young people. In fact, according to data provided by the Spanish Census 2001, young households ${ }^{1}$ (reference person between 18 and 34 years) only represented 16.73 per cent of the total, one of the lowest percentages in Europe.

Young people are certainly among those most affected by the economic cycle which influences directly their employment possibilities, and the housing market scene. Particularly, this group encounters both negative and positive aspects as regards their housing situation (Abramsson et al, 2004): on the one hand, they do not have much experience as actors concerning a residential choice and, besides, they do not have much economic stability. On the other, they are more adaptable and flexible to available residential choices than other demand segments such as parents with children or aging population.

In addition, the process of emancipation is, indeed, the first step of a sequence of household moves. The choice at this very early stage will condition the following housing alternatives all over the life cycle of the household: a young couple who starts living together in a public rented house paying low rents might have a very different housing future than a similar couple who

\footnotetext{
${ }^{1}$ Reference person is aged between 18 and 34 years old.
} 
move to an owner-occupied house assigning a considerable amount of their income to pay back their mortgage. Thus, a wrong move at the beginning might influence the rest of the process.

Since the mid-nineties and till the beginning of the 2000s, both emancipation age and rate of emancipation evidenced in Spain a delay in household formation. That is, there was an increase in the age of nest-leavers and a decrease in the emancipation rate, number of young people who left the parental home ${ }^{2}$. The singular circumstances of the housing market jointly with the supply of precarious labour opportunities for young people have certainly influenced both issues. According to the CES ${ }^{3}$ and based on the EPA-former methodology, in 1977, 44 per cent of the people with ages between 20 and 34 were emancipated, while in 2001, this percentage had declined to 33. This situation varies depending on gender, more women are emancipated; range of age, lower rate of emancipation between 20 and 25; and being or not immigrant, immigrants tend to emancipate more than natives. However, although the age of emancipation in Spain has increased since the nineties and is still high ${ }^{4}$, a change in the landscape is perceived when looking at the evolution of the emancipation rate in recent years ${ }^{5}$ (See Figure 1).

\section{Figure 1. Emancipation rate in Spain}

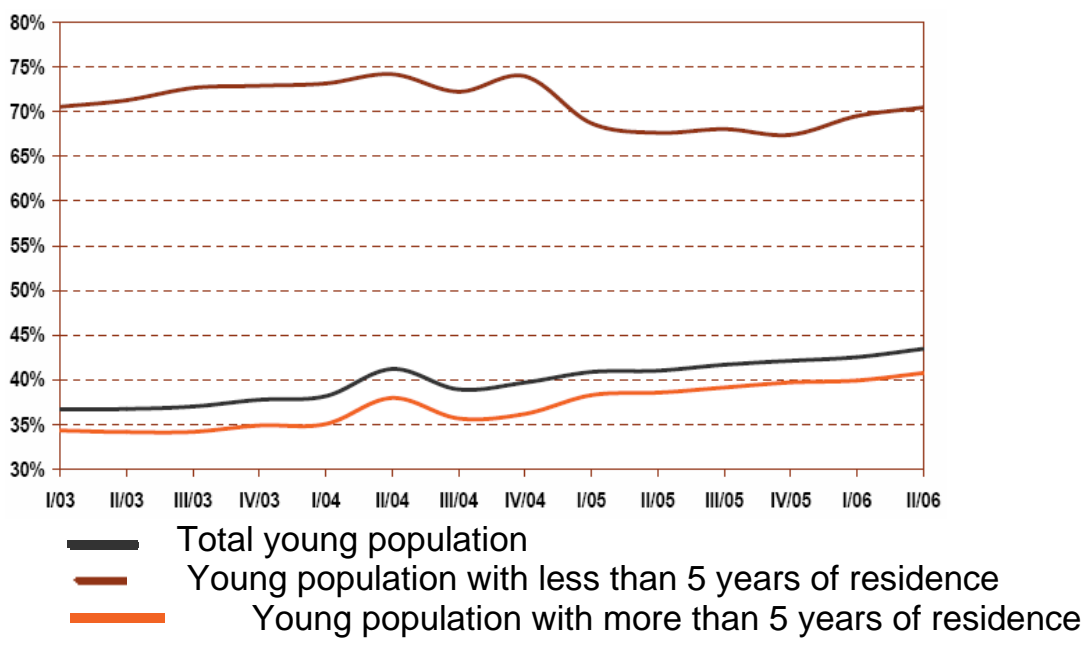

Source: OBJOVI, report $2^{\text {nd }}$ trimester, 2006 based on EPA (2005 methodology)

In the last trimester of 2006, 44.3 per cent of the young population was emancipated in Spain. The change of the economic cycle and the wider range of job opportunities might have favoured emancipation but the most determinant explanation for this turning point in emancipation rates can be found in the increase of the representativity of immigrants in the sample and a change in the labour market context. The variables attributed to the housing market and the residential

\footnotetext{
2 For a complete analysis of young emancipation in Spain during the nineties see, for instance, J. Leal (1997) "Emancipación y vivienda" and P. Serrano, (1997) "La vivienda como determinante de la emancipación juvenil” both in R. Vergés (1997) (ed). La edad de emancipación de los jóvenes. pp. 91-98. Serie Urbanitas. Centre de Cultura Contemporània de Barcelona. Barcelona.

${ }^{3}$ La emancipación de los jóvenes y la situación de la vivienda en España. Consejo Económico y Social. Colección Informes. Informe 3/2002

${ }^{4}$ In 2005, the average age of emancipation in Spain was 30 years for males and 28.2 for women (Requena, 2006)

${ }^{5}$ A change in the EPA methodology might offer certain inconsistencies in annual percentages. Young people are those between 18 and 34 years old.
} 
opportunities for young people do not positively contribute to this change as, following the OBJOVI, in 2006, the housing cost ${ }^{6}$ represented, for young people or households, about 69 per cent of their income, similar to the percentage in 1993 (see Figure 2).

Figure 2. Evolution of housing costs in percentages over familiar income in Spain for young people. 1991-2006

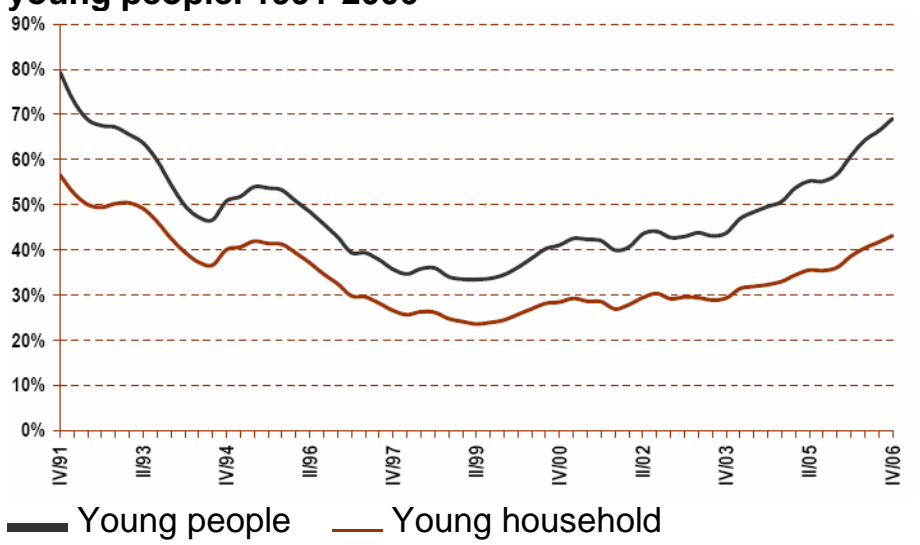

Source: OBJOVI, $4^{\text {th }}$ trimester

From the housing perspective, a paradox is served: while the housing costs have reached the highest level of the past 13 years, the emancipation rate has increased. Several questions arise concerning the current situation of those already emancipated: what are their living standards? Or, in other words, how much of their income goes towards paying back mortgages or rents? Up to what extent young Spanish households are determined forever by their housing choice at the moment of emancipation? Are there any other attractive residential alternatives rather than owner-occupation for them?

The aim of this article is to explore how the traditional and well-known conditions of the Spanish housing market have determined or failed to determine the process of emancipation of youngsters and, up to a certain extent, the rest of their housing careers. The first section will develop the theoretical framework which links emancipation to housing market conditions. The following sections will deal with this relationship in the specific Spanish context, first, regarding preferences of young people and second, examining their residential opportunities. Finally, some conclusions will be elaborated under the light of the previous sections.

\section{Housing choice: preferences and residential opportunities in the emancipation process}

There is a strong connection between the different periods of the life course of individuals (emancipation, marriage, childbearing, retirement) and their housing choices. The housing career concept understood as "the sequence of dwellings that a household occupies during its history" (Pickles \& Davies, 1985, p. 85), reflects this connection. Many issues are linked to the housing career concept. Mobility, spatial location of households and filtering up or down throughout the sequence of occupied dwellings are, among others, the most remarkable. ${ }^{7}$

\footnotetext{
${ }^{6}$ Understood as the rate between a young household annual income and the annual mortgage payment (80 per loan to value ratio for an average dwelling), considering 25 years and the current interest rate (4.653 for the last trimester of 2006).

7 See for instance, Grisby (1963), Jones (1978) and Kending (1984), for the earliest developments on these topics.
} 
The process of housing and tenure choice is intrinsically linked to the housing market conditions and the interaction of the existing actors (i.e. developers, households, public sector) which determine the available housing opportunities. Certain household characteristics directly affect the process of residential choice; age, size and income are among the most decisive. Housing supply is the space within which households, the demand side, make choices and access housing. Other inputs affect the final decision such as the available financial mechanisms or public policies targeting housing and urban issues. It is clear that, housing market choices are made in a certain context characterised by its particular economy and governmental intervention (Figure 3).

\section{Figure 3. The context of housing and tenure choice}

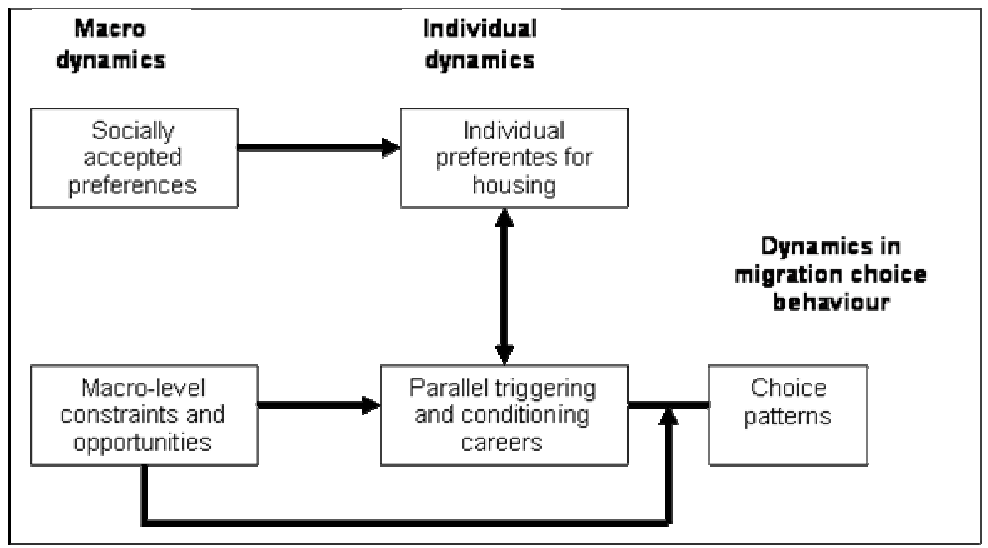

Source: Mulder, 1993, in Clark and Dieleman, 1996.

The process of mobility from one dwelling to another related to the housing career process is therefore understood as a combination of households' preferences and a varied set of constraints (Pareja and Simó, 2005). Preferences are mainly influenced by age, education, income sources, current residential situation and stage in life. Constraints are based, among others, on the household labour situation and the housing opportunities, which are affected not only by the market forces but also by the implementation of current and past policies. In other words, the financial means of each household to pay a rent or a mortgage are essential for a change of housing according to the household's preference. Certainly, as Abramsson et al. (2000) point out: $<<$ on top of individual preferences and resources, the institutional and structural factors have to be taken into consideration, the structure of the housing market, the relationship between supply and demand, housing policies, rules, standards, acting institutions, organisations and agents. They present the housing market from where individuals can (or cannot) choose their dwellings >> (Abramsson et al., 2000, pp. 10)

The main function of mobility from one dwelling to another is the process by which families adjust their housing to housing needs that are altered by life changes, notably the shifts in the family composition (Rossi, 1955). Families move throughout their life cycle and create their particular housing careers: single households, family creation, children, nest leavers and widowers. The beginning of the process usually starts with emancipation from the parental home when another form of shelter is needed and decisions are made in terms of where and when to move. Preferences of nest-leavers and available residential opportunities will determine what type of dwelling will be suitable and affordable for the new household (size, tenure, location). However, some people might postpone the decision until they find the right place to live (Murphy and Sullivan, 1985). 
The concept of housing career is normally associated with progress in standard and quality of housing. But, the definition of "progress" must surely be adapted to the space and time context of the housing career sequence. Does progress always mean to move from the rented sector to owner-occupation? Does it mean a bigger house? Is a better location a synonym of progress? How many moves would be optimal for a "normal" housing career? Clark and Dieleman (1996) argue that: << young households move more often than older households and that those moves are more likely to occur for households in rental housing. Thus, the housing career will be more active and less stable in early stages of the life-course and more regular and more stable in the later stages of the life course >> (Clark and Dieleman, 1996, pp. 145) According to this reasoning, after emancipation, numerous changes of dwellings would be expected in order to achieve "progress" over the housing career. But, what if the first step already involves owneroccupation? As shown in Table 1, and according to ECHP 2001 data, young households in Spain follow a completely different pattern from European young households in terms of tenure. Emancipation in the Spanish context is deeply affected by this fact; young Spanish households will probably not make subsequent moves once they have left the parental home.

Table 1. Distribution of tenure for young households in Spain and Europe. ECHP. Last wave, 2001

\begin{tabular}{|c|c|c|}
\hline & Young households in Spain & $\begin{array}{c}\text { Young households in } \\
\text { Europe }\end{array}$ \\
\hline Owner-occupation & 83.8 & 59.7 \\
\hline Multifamily dwellings & 59.2 & 18.6 \\
\hline Single family dwellings & 24.6 & 41.1 \\
\hline Rented sector & 16.2 & 40.3 \\
\hline Cheap rents(*) & & 7.6 \\
\hline Private & & 4.8 \\
\hline Social Housing & & 2.8 \\
\hline The rest & 14.5 & 32.7 \\
\hline Private & 13.5 & 21.4 \\
\hline Social Housing & & 11.3 \\
\hline Total & 100 & 100 \\
\hline
\end{tabular}

Source: ECHP, in : Pareja, M. and San Martin, I (2003)

$\left.{ }^{\star}\right)$ rents under the 50 per cent of the average rent

Usually, ownership is considered as the apogee of the housing career ${ }^{8}$ when satisfaction achieves its maximum. As Mulder (1993) points out, there are three reasons which explain why owner-occupation is preferred to the rented sector:

- The quality of owner-occupied housing is often better than that of the rented accommodation

- An owner-occupied house is regarded not only as a consumption good but also as a form of investment commodity, especially when interest rates are very low.

- Owner-occupation gives a greater sense of security to owners and they are more in control of their housing situation.

However, this form of tenure has certain costs, which are not present in the rented sector. The acquisition of a house involves a considerable amount of financial costs (down payment, interest rates and fiscal contributions might be the most important) and other associated costs such as the time used to find the suitable house or the fee paid to real estate agents. Besides, advantages ascribed to homeowners do not apply to all owner-occupiers. People with lower incomes will buy worse dwellings, in less desirable neighbourhoods. Indeed, there is a risk that

\footnotetext{
${ }^{8}$ See, for instance, Kendig, (1984), Myers(1999) or Mulder and Wagner (2001).
} 
these homeowners will be "trapped" in a poorly maintained house in a run-down neighbourhood (Elsinga and Hoestra, 2004). In this situation, few chances emerge to improve the standard of living throughout the different steps of the housing ladder. Except, of course, in those cases when a housing price boom allow families, even those located in the worse neighbourhoods, to sell their owned dwelling and buy a new one with a new mortgage. This has been the case for many Spanish households during the past housing boom.

Currently, most European countries are facing difficulties in providing adequate housing for their citizens. In particular, households have fewer possibilities to choose their dwellings as housing policy expenditure has been dramatically cut. Less subsidies and the privatisation of public dwellings reduce choices for households. However, in countries such as Spain, without tradition in providing wide public support for forms of tenure other than owner-occupation, offer a very simplistic tenure system which determines, in many cases, ownership as the only alternative. Therefore, the expected first step of the ladder, the move from parental home to an inexpensive dwelling followed by further steps as the household situation changes is threatened by the nonexistence of such an inexpensive dwelling in the market. Mulder and Wagner (2001) conclude the following: given that being a home-owner might represent one of the most important achievements in everyone's life (Lassarre, 1986; Saunders, 1990) and taking into account that renting usually $y^{9}$ represents a satisfactory alternative, home-ownership can be postponed and not, or at least, not forever, life course events such as parenthood or co-existence.

Certainly, the Spanish context proves the opposite at the first stage of the housing career. The majority of emancipated households access ownership at the very beginning of their housing career. Following this argument, Roca Cladera (1998) argues that "second best" choices of young emancipated households in terms of location, quality and dwelling characteristics but nevertheless, affordable, might lead to a spatial redistribution rather than to delays in leaving their parental home. In fact, one of the determinants to understand internal residential migration of young people is household formation. ${ }^{10}$

Besides the spatial effect of young people choices at the moment of emancipation, the existence of stronger family links as an alternative to well-established welfare policies in Southern Europe certainly plays a key role in the process of household formation of young individuals as <<family strategies shape housing practices in a number of ways >> (Allen et al, 2005, p.146.). According to these authors, three forms of family support to ownership must be mentioned: i) financial aid, ii) self-construction and iii) acquisition of a site where to build. As we shall see further down, financial aid of Spanish parents to their offspring consists in two forms of aid: backing the new mortgage and giving lump sums to contribute to the initial down payment.

\section{Preferences of Spanish youngsters}

When analysing preferences of young people, two considerations must be made. On the one hand, how they prefer to live (i.e. alone, with their parents, with friends) and on the other, which type of housing is suitable for their needs. A survey was conducted in September 2005 by INJUVE $^{11} ; 1,466$ young people between 18 and 34 were interviewed. 50.5 per cent lived in their parental house, 42.4 per cent lived in their own house and the rest in other residential forms (for instance, with friends).

According to this source, the majority of Spanish young people, 8 out of 10 , would prefer to live independently in their own house, rented or owned. This represents 82 per cent of those

\footnotetext{
${ }^{9}$ Own cursive

${ }^{10}$ See Mòdenes and Recaño, 2003, for an analysis of the Catalan case

${ }^{11}$ INJUVE, Sondeo de opinión y situación de la gente joven. 3a encuesta de 2005.
} 
interviewed, which shows an increase in 5 points since 1996. 1 out of 8 declares the parental home as their first choice (13 per cent in 2005, 12 per cent in 1996) and 1 out of 25 affirms that living with friends and colleagues would be their first preference.

For those who do not like their current housing situation, the reasons behind their discontent in relation to the place they live are basically related with their economic stability (58.2\%). The housing price emerges as a main reason for dissatisfaction as they become older. In fact, 67 per cent of those who bought a house, had their own savings and 51 per cent counted with their partners' savings. The role played by parents, who either transferred money or/and backed the mortgage, was considerable. The survey also points out that those youngsters living independently are satisfied with their housing conditions. Only 5 per cent are dissatisfied.

Considering the reasons behind emancipation, as mentioned before, the most relevant is marriage or cohabitation with partner (see Table 2).

Table 2. Reasons for moving out the parental home. In percentages.

\begin{tabular}{ll}
\hline \hline Marriage or co-existence & 56 \\
Independence and own a house & 20 \\
Labour reasons & 12 \\
Education & 10 \\
\hline \hline
\end{tabular}

Source : INJUVE, 2006

Difficulties of housing access together with owner-occupation as a priority during the first steps of the Spanish household's housing career entails lower rate of mobility in Spain than in the rest of Europe. In 2005, 76 per cent of young Spanish households have previously lived in their parental home (INJUVE).

For those already emancipated, the most important requirement asked of their new house was that the price was affordable (42.8\%) followed, at a distance, by the desire that it was located close to their job or study place (24.0\%). $47.6 \%$ of emancipated young people live in an owneroccupied house with pending mortgage payments and $31.9 \%$ in a rented house. Calculations on the number of years for the mortgage to be completely paid back evidence that, for those aged between 18 and 19, 35.0 years were needed, for those between 20 and 24, 20.5 years, for those between 25 and 29, 21.8 and for the young between 30 and 34, 18 years have to pass. This enormous difference between ranges of age shows one of the current characteristics of the mortgage market in Spain, that is, the period to pay back the loan has extended considerably in the recent past.

For those emancipated living in an owner-occupied house, the average amount paid for a monthly mortgage quota was 460.8 euros while those living in the rented sector paid an average rent of 425.4 euros. The insignificant difference between the monthly mortgage quota and the monthly rent clearly explains why young people, and also other segments of population, prefer to live in an owner-occupied house rather than in a rented house. Thus, they pay not only for consumption of housing services but also for an investment commodity, The traditional cultural preference for owner-occupation in Spain and other Southern countries argued by some authors (i.e. Allen et al., 2006) has to be accompanied, probably, by strong economic reasons. In fact, when those living in the rented sector were asked about the reasons why they have chosen this type of tenure, affordability of owner-occupation was pointed out as the main argument (see Table 3) 
Table 3. Reasons why they live in the rented sector

\begin{tabular}{|c|c|c|c|c|c|}
\hline \multirow[b]{2}{*}{ Reasons } & \multirow[b]{2}{*}{ Total } & \multicolumn{4}{|c|}{ Age ranges } \\
\hline & & $18-19$ & $20-24$ & $25-29$ & $30-34$ \\
\hline $\begin{array}{l}\text { Impossibility to afford an owner- } \\
\text { occupied house }\end{array}$ & 63 & 50 & 46 & 67.8 & 69.5 \\
\hline $\begin{array}{l}\text { For future movements because of work } \\
\text { or study reasons }\end{array}$ & 13.5 & 25 & 20 & 15.6 & 6.1 \\
\hline Transitory situation & 18.3 & 12.5 & 26 & 13.3 & 19.5 \\
\hline Other reasons & 3 & & 4 & 1.1 & 4.9 \\
\hline $\mathrm{NS} / \mathrm{NC}$ & 2.1 & 12.5 & 4 & 2.2 & \\
\hline Total & 100 & 100 & 100 & 100 & 100 \\
\hline
\end{tabular}

Source : INJUVE, 2006

More than 60 per cent of those youngsters already emancipated underlined the absence of economic support from their parents when moving out of the parental home. 40.3 per cent enjoyed a protected house (Vivienda de Protección Oficial) and 28.4 per cent had benefited from an interest rate reduction in their mortgage.

When young people living with their parents were asked about their tenure preferences, 90 per cent acknowledge preferring the owner-occupied sector rather than a rented dwelling. Interviewees were asked for the reasons behind such a preference: as Table 3 points out, "rents are expensive" was selected by 45.6 per cent of the sample followed by "to have my own house" chosen by 44.2 per cent. According to estimations on housing prices and rents in Spain (BBVA) similar housing expenditures are associated to both forms of tenure (i.e. for almost the same monthly amount of housing expenditure, in one case, they become owners of the dwelling and in the other; they just enjoy the housing services provided).

Table 4. Reason to prefer the owner-occupied sector

\begin{tabular}{lc}
\hline \hline Rents are expensive & 45.6 \\
To avoid the insecurity of a rented dwelling & 5.6 \\
Bad conditions of rented dwellings & .7 \\
To avoid bureaucratic problems & 1.7 \\
To have "my" own house & 44.2 \\
Other reasons & 1.5 \\
NC no answer & .7 \\
\hline Total & 100 \\
\hline \hline
\end{tabular}

Source : INJUVE, 2006

Concerning the future of those still not emancipated, more than 62.7 underlined that moving out of the parental home either to a rented or to an owner-occupied dwelling would entail receiving economic support from their family.

To sum up, economic instability and lack of affordable housing determine the permanence at the parental home longer than before. Given the Spanish market conditions, young households, as the rest of households in Spain, would prefer to own a house rather than rent it due to the similar housing expenditures associated to both forms of tenure. Certainly, once ownership is decided, the help of the partner's income and even the help of parents are decisive. 


\section{Residential opportunities in Spain}

Residential opportunities in the housing market directly depend on the current structure of housing supply and demand. Tenure, prices, rents, existing dwelling and current construction are, among others, elements which determine the existing possibilities for those emancipated. Certainly, housing policy means (i.e. interest rate subsidies, grants etc.) will definitely alter the available opportunities ${ }^{12}$.

Housing markets in Western Europe and, particularly in Spain, show common characteristics which deeply affect the behaviour of households in the housing market, especially of those who start their own housing career throughout the emancipation process. A profound shift from a predominantly renter to a predominantly owner-occupied society has taken place in the majority of countries. The process started earlier in Spain as the implementation of housing policies since the 60 s stimulated this form of tenure. Currently, Spain counts with the lowest public rented sector in Europe and with one of the highest ownership sectors (see Figure 4).

\section{Figure 4. Tenure in Spain}

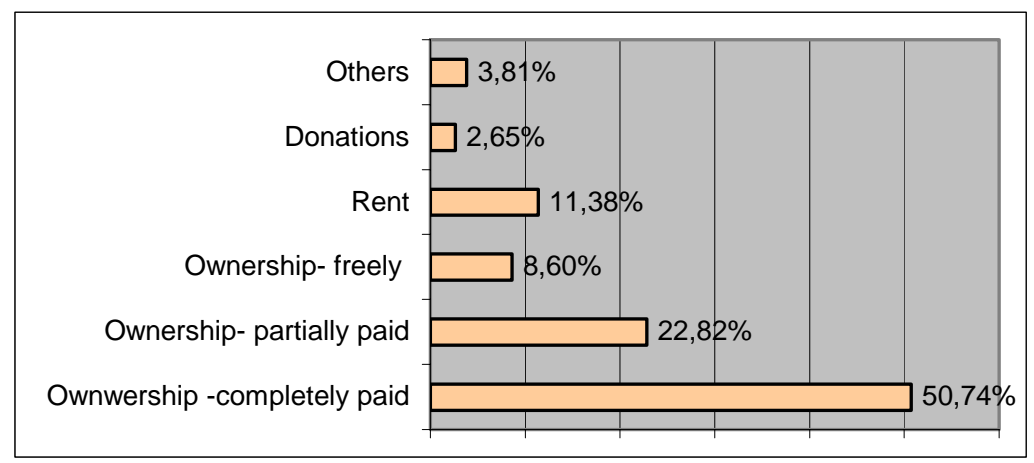

Source: INE 2004. Censos de Población y Viviendas 2001. Resultados definitivos.

The following factors determined the Spanish housing situation until 2006:

- The country enjoyed favourable economic conditions from 2004 onwards, that is, low unemployment rates, and high rates of GDP growth.

- The economic prosperity was partially supported by a extraordinary dynamic building sector

- Developers and investors generated great expectations based on the high rise of housing prices

- Low interest rates till 2006 and financial facilities have encouraged the demand side of the housing market

- General increase in the demand side as the baby boom generation started to emancipate

As a consequence of these stimulating economics factors, a sharp increase in the construction of owner-occupied dwellings, mainly belonging to the free market, occurred. In the same period, the scarce construction of protected and rented dwellings especially those public (See Figures 5 and 6) continued. Simultaneously, the problem of housing access became more and more dramatic. In spite of the high rate of new construction, the scarcity of affordable dwellings was evident. Low income families, young people and immigrants were the more vulnerable collectives as they could not afford housing market conditions (neither prices nor rents) and

\footnotetext{
12 In this section, attention is not paid to housing policy and its instruments as an additional mechanism to facilitate housing access or enlarge residential opportunities for young individuals and households.
} 
were forced to live in sub-standard dwellings in terms of location and facilities (SOCOHO, final report, 2003). Given that affordable dwellings in Spain are located in the periphery or in less desirable locations, a spatial consequence of the mismatch between demand needs and available supply has caused newly formed or young households to move to less central municipalities (Módenes, J.L. and Recaño, 2003))

Figure 5. Starts of dwellings. 1991-2006

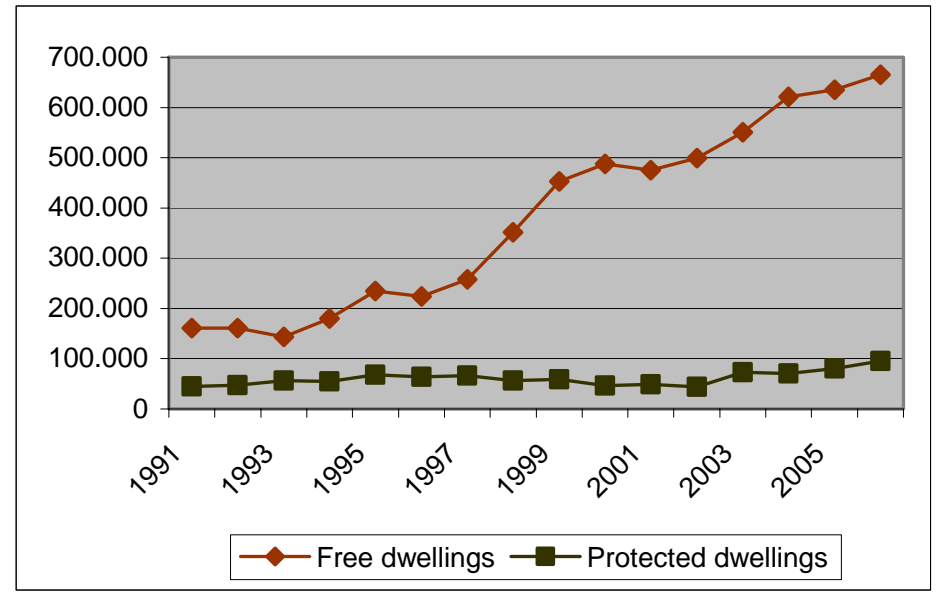

Source: Ministerio de Vivienda

Figure 6. Finished dwellings. 1991-2006

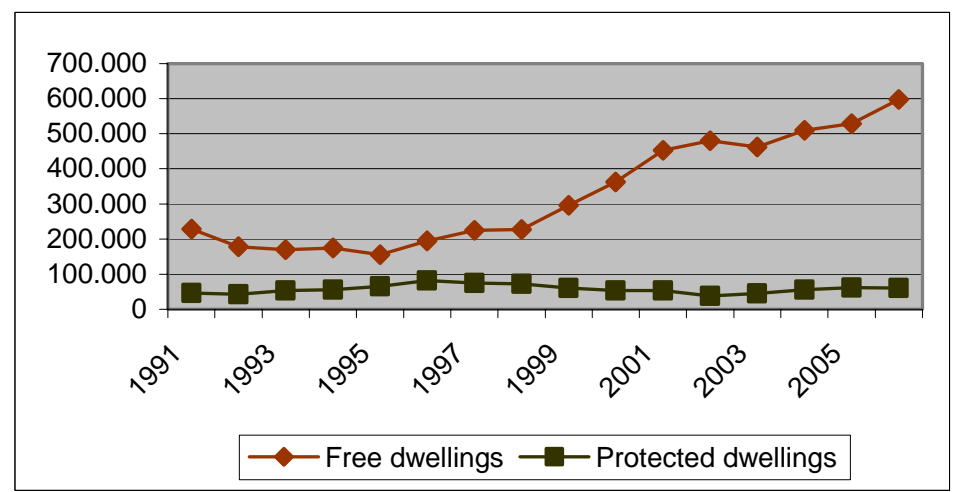

Source: Ministerio de Vivienda

The high rise in house prices (see Figure 7) together with the scarcity of affordable rented dwellings (Figure 8) turned the housing access of certain collectives into one of the main problems of the country. In particular, the postponed emancipation process has hidden a "discouraged demand", which would probably worsen even more, if on the market, the housing situation (Pareja and San Martin, 2001). 
Figure 7. Housing prices in Spain. Percentage of year-on-year variation.

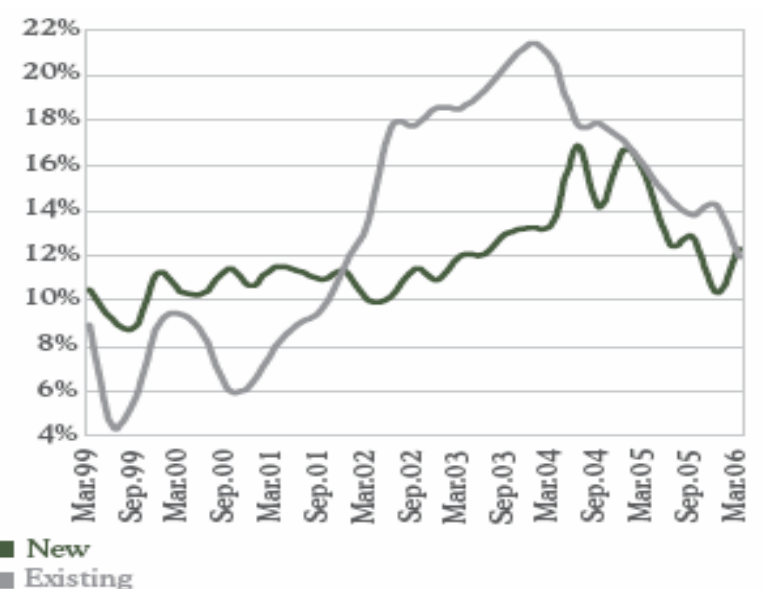

Source: Research Department. BBVA.

Figure 8. Rented dwellings by monthly rent (Thousands of dwellings)

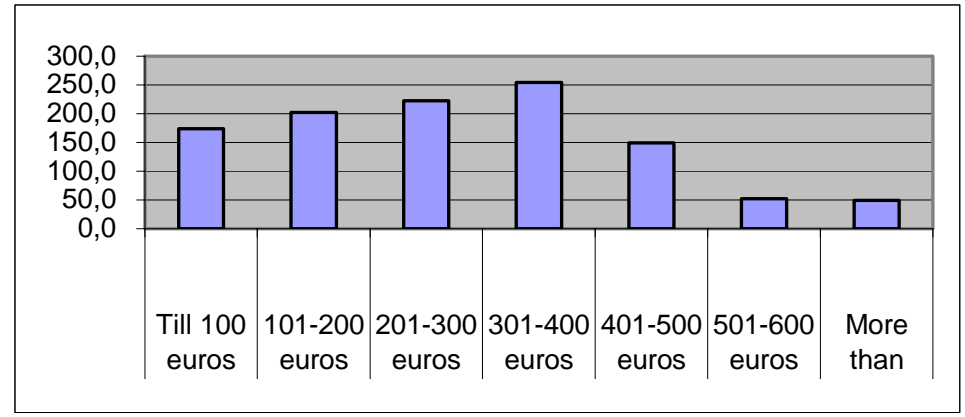

Source. Ministerio de Vivienda

Certainly, affordability ratios are currently the worse in the last 12 years. The deterioration of these ratios is explained by the fact that housing prices growth has been higher than the growth of household income. For instance, while housing prices increased in 2005, 9.11 per cent, the average salary perceived by young people only increased 3.43 per cent. The situation of the housing market for young people is not identical in all Autonomous Communities as the average household income range addressed to buy a house varies from 57 per cent (Madrid, Basc Country and Balearics) to 31 per cent ( Navarra and Extremadura).

The 2006 figures show that a household with average income would need the equivalent of 5.6 years' gross income to buy an average home. The figure for 2005 was 5.2 years. Estimations for 2007 suggest that this ratio will deteriorate in 2 points (BBVA) because, although the market offers a better situation in terms of housing price increase, housing expenditures for already existing mortgage quotas are going up.

According to the last survey conducted by the Ministry of Housing in 2006, the narrow Spanish rented sector is not equally distributed among age ranges. The over-represented age range segment in the rented sector is the one which corresponds to those aged between 36 and 50 years old, (33.26\%). The following group are those aged between 18 and 35 which occupy 23.93 per cent of the rented dwellings and are followed by those between 51 and $65(22.87 \%)$ and those older than 65 (19.94\%). 
Therefore the key question is what type of dwelling can young households afford? Taking into account that, theoretically, no more than 30 per cent of the household income should be addressed to housing acquisition, and given the mortgage financial conditions, young people can possibly only afford small, bad located and low quality dwellings. As OBJOVI points out $<<$ during the last trimester of 2006, the maximum size of an affordable dwelling for a young individual with a salary as the only income source is 43.4 square metres, a surface 17.76 per cent smaller than in the past year $>$. In practise, nowadays young households assign, on average, 69 per cent of an individual salary and 43.2 per cent of household income on housing payments (OBJOVI, 2007). Given the scarcity of small dwellings in Spain, a trade-off between size and quality of the dwelling for young households, especially first-time buyers, is mandatory. This means that, if they cannot access small dwellings given the lack of supply of this type of housing in Spain, young households will opt for larger houses but possibly more deteriorated and worse located.

However, since 2006 the market has been cooling down: housing prices growth rate is lower ${ }^{13}$ and the activity in the housing market is less dynamic ${ }^{14}$. The ease of the housing demand is noticeable in the fact that it takes longer to sell a house once in the market, the stagnation of the number of transactions and the lower demand for housing loans. As a consequence, and following the usual rule during periods of recession in the free market, protected dwellings have become more attractive to developers since their future acquisition is guaranteed. According to BBVA (2007), after a period of strong growth in activity, spending and price levels, the Spanish property sector is gradually stabilising in 2007. There are several factors which influence this process. Firstly the slow down of the demographic pressure of baby boomers in the market given that they all have access housing in the past decade the increase in employment and demand for housing of non-residents and less expansionary financing conditions. This adjustment also affects the young population, not only those still living with their parents and expected to emancipate in the near future but, especially, those who left the parental house during the period of highest housing prices.

For the first group, an uncertain future is ahead. Positive variables will facilitate their housing access, related to the slow down of the housing prices growth and the action of public policies, mostly throughout the rented sector, started in 2004 in order to stimulate housing accessibility for young population. Nevertheless, the hardening of financial conditions will obstruct the achievement of former favourable conditions offered by the banking system.

For the second group, that is, those recently emancipated, the situation is, unfortunately, critical.

(1) Firstly, expectations on the increase of their housing patrimony are blurred given the slow down of housing prices growth since 2005. Certainly, this will affect more negatively those who bought a house as an investment commodity. Thus speculation is being punished.

(2) Secondly, they will suffer the consequences of the changing conditions in the financial markets (i.e. increase of interest rates). In fact, indebted households will feel in the near future the effect of increased interest rates (4 per cent) as mortgage loan rates are currently revised upwards. ${ }^{15}$. Young households will particularly be negatively affected. As shown in Table 4,

\footnotetext{
${ }^{13}$ In the second trimester of 2007 , housing prices grew 5.8 per cent, the lowest rate in the last 9 years.

${ }^{14}$ The amount of starts and finished dwellings decreased in the first trimester of 2007.

${ }^{15}$ The Euribor index has followed an upward trend since 2005 (Euribor July 2005=2.168 per cent; Euribor July $2007=4.564$ per cent) and since it is the most used index to update mortgage quotas, Spanish families which already have compromised a high percentage of their income in the housing mortgage quota will see an increase in their monthly payment ${ }^{15}$.
} 
according to different sources, young household families in Spain are highly indebted. This fact leaves them highly exposed to changing financial conditions.

Table 5. Payments per debts (mortgage included)/ household income

\begin{tabular}{cccc}
\hline \hline $\begin{array}{c}\text { Age of household } \\
\text { head }\end{array}$ & $\begin{array}{c}\text { Median \% } \\
\left(^{*}\right)\end{array}$ & $\begin{array}{c}\text { Percentage of } \\
\text { households with values } \\
\text { over } \mathbf{4 0} \%\left(^{*}\right)\end{array}$ & Indebt rate $\left(^{* *}\right)$ \\
\hline Less than 35 years & 17.2 & 8.8 & 17.2 \\
Between 35 and 44 & 16.7 & 7.2 & 16.7 \\
Between 45 and 54 & 13.1 & 7 & 13.1 \\
Between 55 and 64 & 12.9 & 5.7 & 12.9 \\
Between 65 and 74 & 11.7 & 5.9 & 11.7 \\
More than 75 & 16.7 & 9.2 & 16.7 \\
\hline Total & 15.2 & 7.2 & 15.2 \\
\hline \hline
\end{tabular}

Source: EFF. Boletin Económico del Banco de España. In Mullor Gómez, (2007)

${ }^{*}$ ) Obtained by EFF. Encuesta Financiera de las Familias

$\left.{ }^{\star *}\right)$ Indebt rate: relationship between acquired compromises of payments for debts and household (individual, collective...) income. Obtained by the Genworth study

(3) Finally, as we saw before, long term mortgage requirements acquired by many Spanish households, especially young people during their first housing access to owner-occupation will determine their future progress along their housing career. In many cases, they will be kept in a non-desirable dwelling and/or location and, although their life cycle progress and other life course events will occur, possibilities to adapt this changing situation to their housing needs will be highly threatened.

\section{Conclusions}

This article analyses both the role played by the housing market in the emancipation process of young individuals and households. Concepts from housing career literature have been used to develop certain hypothesis to be tested in the Spanish case, an owner-occupied dominated market.

The scarcity of affordable dwellings determines a later emancipation of the young population, who stay with their parents longer and in many cases they only move out because of marriage or co-habitation with a partner. Once emancipation is decided, the majority of new households in Spain opt for the owner-occupied sector. Even when those still living with their parents are asked, they prefer to buy rather than to rent. The preference for this form of tenure is certainly affected by the scarcity of affordable dwellings in the rented sector and the lack of alternatives.

Positive aspects are derived from this early access to owner-occupation for expected housing quality is higher in the owner-occupied sector than in the rented one. Family solidarity is evident in many cases. Families support the offspring in moving out. Besides, households also consider their acquisition as a form of investment together with their consumption of housing services. However, there are negative issues too. The choice for ownership forces young households to accept "second best" solutions. They buy housing in a less preferred environment or with a substandard quality. This fact together with the strenuous effort they make in paying their monthly housing expenditures, condemn them to stop their progress throughout their housing careers unless substantial increases in value of their housing, or instance, in a housing price boom, 
allows them to continue. This form of "trap" is especially dangerous for those who emancipated while favourable financial conditions were at hand.

In this sense, the current stimulus to the rented sector from policy-makers is absolutely necessary, especially in those places where housing access is even more difficult than usual given the lack of affordable rented dwellings. The current upward trend in interest rates increases the urgency.

\section{References}

Abramsson, M; Fransson, F and Borgegård, L-E. (2004) The first years as independent actors in the housing market: Young households in a Swedish municipality. Journal of Housing and the Built Environment. No. 19, pp. 145-168. Kluwer Academic Publisher

Abramsson, M.; Fransson, U.; Borgegård, L-E. "Housing careers-some empirical evidence of a complex concept" paper presented at the ENHR Conference "Housing in the 21th Century: Fragmentation and Reorientation", Gävle, Sweden, 26-30 June 2000

Allen, J.; Barlow,J. ; Leal, J.; Maloutas, T. and Padovani, L. (2004) Housing and Welfare in Southern Europe. Real Estate Issues. Blackwell Publishing, Ltd.

CES - Consejo Económico y Social - (2002) La emancipación de los jóvenes y la situación de la vivienda en España. Colección Informes. Informe 3/2002

Clark, W. A.V.; Deurloo, M. and Dieleman, F (2003) Housing Careers in the United States, 1968-93: Modelling the Sequencing of Housing States. Urban Studies, Vol. 40, No. 1, pp. 143160. Carfax Publishing

Clark, W. A.V. and Dieleman, F. (1996) Households and Housing. Choice and Outcomes in the Housing Market. Center for Urban Policy Research. Rutgers - The State University of New Jersey.

Grigsby, W. (1963) Housing Markets and Public Policy. Philadelphia: University of Pennsylvania Press.

INJUVE (Instituto de la Juventud) (several years) OBJOVI reports - Observatorio joven de vivienda en España. Boletin trimestral de seguimiento de la relación entre los jóvenes y la vivienda en españa y en cada una de las Comunidades Autónomas. El acceso de los y las jóvenes a la vivienda libre y protegida. Consejo de la Juventud en España.

Jones, C. (1978) Household Movement, Filtering and Trading up within the Owner-Occupied Sector. Regional Studies, No. 12, pp. 551-561.

Jurado Guerrero, T. (2006) Los jóvenes. Un potencial para el cambio de modelo de vivienda Foro Civitas Nova 2006. Vivienda, urbanismo y Sostenibilidad en la ciudad de hoy. Electronic publication.

Kendig, H. L. (1984) Housing careers, life cycle and residential mobility: implications for the housing market. Urban Studies, No. 21, pp. 271-283.

Lassarre, D. (1986) Moving into home ownership. Journal of Economic Psychology, No. 7, pp. 161-178. 
Leal, J (1997) “Emancipación y vivienda" in R. Vergés (1997) (ed). La edad de emancipación de los jóvenes. Serie Urbanitas. Centre de Cultura Contemporània de Barcelona. Barcelona.

Mòdenes, J.A. and Recaño, J. (2003) El territory i la mobilitat migratòria dels joves a Catalunya. Aportacions 22. Generalitat de Catalunya.

Mulder, C. and Wagner, M. (2001) The Connections between family Formation and First-time Home Ownership in the Context of West Germany and the Netherlands. European Journal of Population, No. 17, pp. 137-164. Kluwer Academic Publishers

Mulder, C. (1993) Migration Dynamics: A Life Course Approach. Amsterdam: Thesis Publishers.

Mullor Gómez, L. (2007) Estudio sobre los diferentes indicadores a la accesibilidad a la vivienda. Ministerio de Vivienda.

Murphy, M.J. and Sullivan, O. (1985) "Housing tenure and family formation in contemporary Britain" European Sociological Review, No. 1, pp. 230-243

Myers, D. (1999) Cohort Longitudinal Estimation of Housing Careers. Housing Studies, Vol. 14, pp. 473-490.

OBJOVI - Observatorio Joven de Vivienda en España (several years) Boletín trimestral de seguimiento de la relación entre los jóvenes y la vivienda en España y en cada una de las Comunidades Autónomas. Consejo de la Juventud de España.

Pareja-Eastaway, M. and Simó, M. (2005) Residential choices and mechanisms of adaptation: households' strategies in large housing estates in Europe. Paper presented at the ENHR Conference "Housing in Europe: New Challenges and Innovations in Tomorrow's Cities", in Reykjavik, June 2005.

Pareja-Eastaway, M. and San Martin, I (2003) The importance of housing systems in safeguarding social cohesion. SOCOHO Final report.

Pareja Eastaway and San Martin, I (2002) The Tenure Imbalance in Spain: The Need for Social Housing Policy. Urban Studies, Vol. 39, No. 2, pp. 283-295.

Pickles, A.R.; Davies, R.B. (1985). The Longitudinal Analysis of Housing Careers. Journal of Regional Science, No. 25, pp. 85-101.

Requena, M. (2006) "Familia, convivencia y dependencia entre los jóvenes españoles" Panorama Social. Madrid. FUNCAS, No. 3, pp. 64-77.

Roca Cladera, J. (1998) ¿Reducción en la formación de nuevos hogares o redistribución metropolitana delos mismos? In R. Vergés (1998) (ed) El precio de la vivienda y la formación del hogar. Serie Urbanitas. No. 6. Centre de Cultura Contemporània de Barcelona. Barcelona.

Rossi, P. (1955) Why families move? A study in the social psychology of urban residential mobility. Glencoe, IL: Free Press.

Saunders, P. (1990) A Nation of Home Owners. Unwin Hyman, London.

Serrano, P (1997) "La vivienda como determinante de la emancipación juvenil" in R. Vergés (1997) (ed). La edad de emancipación de los jóvenes. Serie Urbanitas. Centre de Cultura Contemporània de Barcelona. Barcelona. 
The Gallup Organisation (2007) Youth survey among people aged 15-30, in the European Union Flash Eurobarometer Series - No. 202

Vergés, R. (ed) (1998) El precio de la vivienda y la formación del hogar. Serie Urbanitas. No. 6. Centre de Cultura Contemporània de Barcelona. Barcelona.

Vergés, R. (ed) (1997) La edad de emancipación de los jóvenes. pp. 91-98. Serie Urbanitas. No. 5 Centre de Cultura Contemporània de Barcelona. Barcelona. 
Architecture, City, and Environment

Arquitectura, Ciudad y Entorno 